\title{
DIRECTIVE SPEECH ACT IN THE MOVIE “SLEEPING BEAUTY”
}

\author{
Muhartoyo; Keilly Kristani \\ English Department, Faculty of Humanities, BINUS University \\ Jln. Kemanggisan Ilir No. 45, Kemanggisan - Palmerah 11480 \\ ymuhartoyo@yahoo.com
}

\begin{abstract}
Pragmatics is one of linguistics studies that is quite attractive to learn more about. There are many aspects of pragmatics; one of them is dealing with speech acts. Speech acts consist of many categories; one of them is directive speech act. This study aims to identify the directive speech act performed in "Sleeping Beauty" movie. Likewise, it will find out how often the directive speech act performed and which type of directive speech act that are most frequently used in the movie. This study used qualitative method in which data collection is done by watching the movie, analyzing the body movement and the dialogues of each character, reading the script and library research. A total of 139 directive speech acts were successfully identified. The result of analysis showed that the directive speech act of ordering is the most frequently used in the movie (21,6\%). The least frequently used directive speech act is inviting directive speech act $(0,7 \%)$. The study also revealed the importance of directive speech act in keeping the flow of storyline of the movie. This study is expected to give some useful insights in understanding what directive speech acts is.
\end{abstract}

Keywords: pragmantics, directive speech act, sleeping beauty movie

\begin{abstract}
ABSTRAK
Pragmatik merupakan salah satu cabang ilmu Linguistik yang cukup menarik untuk dipelajari. Ada banyak aspek sehubungan dengan pragmatik, salah satunya adalah tindak ujar. Tindak ujar terdiri dari beberapa kategori, salah satunya adalah tindak ujar direktif. Penelitian ini bertujuan untuk mengidentifikasi tindak ujar yang terjadi di film Sleeping Beauty. Lebih lanjut, penelitian ini bertujuan untuk mencari seberapa sering tindak ujar direktif yang terjadi dan tipe tindak ujar yang paling sering digunakan di film. Penelitian menggunakan metode kualitatif dengan data diperoleh dari menonton film, menganalisis gerak tubuh dan dialog para karakter pemain, membaca naskah, dan kepustakaan. Terdapat 139 tindak ujar direktif berhasil diidentifikasi. Hasil analisis menunjukkan tindak ujar direktif ordering adalah yang paling sering digunakan di film (21,6\%). Sementara tindak ujar direktif inviting adalah yang paling sedikit digunakan (0,7\%). Penelitian juga menemukan pentingnya tindak ujar direktif dalam menjaga alur cerita. Penelitian ini diharapkan dapat memberikan pemahaman yang bermanfaat tentang tindak ujar direktif.
\end{abstract}

Kata kunci: pragmatik, tindak ujar direktif, film Sleeping Beauty 


\section{INTRODUCTION}

Language is a sound of symbols that convert some words in mind into a sentence of spoken words (Yule, 1996). In communication, we need a partner or a hearer to understand and respond what we talk about. Speakers and hearers usually use the same language to communicate so the message can get across easily. But, in some communication cases, speakers could not get their messages across due to a different cultural background or divergences. Divergences may result in some misunderstanding between interlocutors or hearers and speakers in a conversation. Consequently, the message will not be easily well delivered to hearers as the way it is. Some ways to avoid that kind of misunderstanding is by learning about pragmatics which deals with meaning based on its social context. Pragmatics has many aspects; one of them is speech acts. Meanwhile, speech acts consist of several categories, one of them is directive speech acts. Having learned the principles of speech acts we will be able to implement them in the daily social interaction in our life. Speech acts are part of Pragmatics.

There are several definitions about pragmatics. According to Stanford Encyclopedia of Philosophy (2006), Pragmatics is the utterances of specific events and the intention of the speaker to the hearer at times and places involving language. Pragmatics consists of several aspects including context, deictic, presupposition, implicature, and speech acts. Speech acts is a central point of pragmatics. In communication, we use utterances in acting that is known as speech acts. Speech acts themselves can be divided into three elements/aspects: locutionary, illocutionary, and perlocutionary. According to Yule (1996), there are five types or categories of speech acts, namely: declaration, representative, directive, commisive, and expressive.

Due to limited space and time the analysis will only focus on the directive speech acts coupled with the explanation of locutionary, illocutionary and perlocutionary aspects. The analysis will cover locutionary, illocutionary and perlocutionary aspects because they are the main point of speech acts.

The source for data collection will be the movie entitled Sleeping Beauty. This movie is quite interesting as it contains many dialogues which are good source for data analysis of this study, especially from the angle of directive speech acts. As a matter of fact directive speech act is frequently used in daily social interactions around us. Directive speech acts is a common acts that people around the world usually use. It is easier to study and understand something that always happens rather than something uncommon. It is even more interesting because it happens in real life. The above mentioned reasons give a strong motivation to conduct a study about directive speech acts. It will be interesting to learn and explore the importance of directive speech acts by means of analyzing the "Sleeping Beauty" movie as a sample for data collection that will be elaborated in detail in the data analysis. There are three questions that will be answered by analyzing the dialogues in this movie, i.e.: (1) How often does the directive speech acts appear in the dialogue in the movie? (2) Which type of directive speech acts are most frequently used in the movie? (3) What is the importance of directive speech acts in the movie?

This research is intended to make readers understand more about directive speech acts. By watching this movie, the viewer will learn about words, action and utterances. The viewer can learn about pragmatics, especially speech acts by observing the dialogues and their context in every scene of the movie. The viewer can see the importance of directive speech acts in keeping the smooth flow of the story lines of the movie. The viewer can also learn grammar, pronounciation, and vocabulary from what they see and hear. They can imitate the action that the characters performing in the movie. 


\section{Theoretical Framework}

Some theories of speech acts related to this research will be explained. First, the definition of pragmatics will be elaborated. Second, it will discuss about speech act. Then, it will explain the theory of locutionary act, illocutionary act and perlocutionary act. Finally it will explain about direct and indirect speech acts, literal and non-literal speech acts and felicity conditions. Felicity conditions need to be explained because it is the part of speech act.

\section{Pragmatics}

Linguistics is "a scientific study of language" (Sinha, 2005). Pragmatics is one of the linguistics studies that describe the meaning of a word, phrase or sentence in their social context. According to Horn and Ward (2004): "Pragmatics is the study of those context-dependent aspects of meaning which are systematically abstracted away from in the construction of content logical form."

In brief, pragmatics can be defined as a study of language that examines contextual meaning of language including speaker's intention and hearer's response or reaction, example: "This cake looks so delicious." In this context, the sentence implied that the speaker wants the hearer to do something for him. For example, the speaker wants the hearer to give him or her the cake.

Pragmatics is concerning with the study of speaker's meaning. This study involves the interpretation about a context in an utterance which requires the same thought between the speaker and the hearer. According to Yule (1996), the definitions of pragmatics are:

i) The study of speaker's meaning

ii) Pragmatics focuses on the study of the meaning of utterances performed by a speaker and interpreted by a hearer.

iii) The study of contextual meaning

iv) Pragmatics focuses on the interpretation of a context in the utterances performed by a speaker.

v) The study of how more gets communicated than is said

vi) Pragmatics focuses on the ability of a hearer to interpret the intended meaning of a speaker.

vii) The study of the expression of relative distance

viii) Pragmatics focuses on the determination of a speaker to decide how much needs to be said.

In conclusion, pragmatics can be defined as a study about the relationship between language and its social context in the process of communication between a speaker and hearer. Pragmatics talks about how people understand the speaker's intention through verbal communication and gestures. In other words, pragmatics also studies how people comprehend and produce a communicative speech act in a conversation.

\section{Speech Act}

Speech act is one of the pragmatics studies. Speech act was first developed by Austin (1962) to explain an utterance with a natural language to get a feedback (Flor and Juan, 2010). Speech act is a phrase that consists of two words, speech and act. Speech act is utterances that can be classified into three aspects i.e. locutionary act, illocutionary act, and perlocutionary act. Speech act can change the social reality not only describing a given reality. Speech act is usually used for making statements, giving commands, asking questions, or making promises.

According to Hurford and Heasley (2007), the alleged distinction between speech and act can cause misleading oversimplification because when a speaker makes an utterance in appropriate circumstances, it leads to a misunderstood interpretation of the hearer. According to Nastri, Peña and Hancock (2006), the function of speech act is a functional unit of language that informs people to do 
things with words, which means the speaker performs an act of saying something in order to participate in a communication. Another function of speech act according to Ahmed (2005) is to visualize the spoken words. Speech act makes all the materials of an utterance can create the impression of saying something, as in an utterance has feelings and thoughts, so the utterance becomes more lively.

There are five basic kinds or categories of speech acts (actions that can be performed in speaking) which mean the five types of utterances developed by Yule (1996).

\section{Declarative}

A kind of speech act that makes the world change by their utterances which means words change the world. In other words, speaker causes the situations change. The declaratives utterances can be divided into some sub-categories such as declaring, confirming, blessing, approving, betting, dismissing, naming, etc.

Example: Judge: I sentence you to death.

This utterance expresses a criminal court's verdict that declares a death penalty to the suspect. In this case, the judge's declaration has a legal binding as it meets the felicity conditions in which the judge is taking his role as a presiding judge in a criminal court session.

\section{Representative}

A kind of speech act that the speaker believes to be the case or not which means words fit the world. In other words, speaker believes the situation. The representative utterances consist of swearing, informing, boasting, asserting, criticizing, denying, claiming, complaining, describing, reporting, suggesting, etc.

Example: The earth is flat.

This representative utterance informs the speaker's belief about the earth.

\section{Expressive}

A kind of speech act that describes what the speakers feel which means make words fit the world. In other words, speaker feels the situation. The expressive utterances consist of condoling, praising, thanking, complimenting, regretting, congratulating, etc.

Example: I like the way you laugh.

This expressive utterance explains the praising utterance.

\section{Directive}

A kind of speech act that the speaker's intention to make someone else to do something which means makes the world fit words. In other words, speaker wants the situation. The directive utterances consist of asking, inviting, ordering, begging, requesting, suggesting, recommending, demanding, permitting, etc.

Example: Don't take that way.

This directive utterance explains the forbidding utterance. 


\section{Commissive}

A kind of speech act that focuses on the speaker's commitment. The speaker commits themselves to some future action which means make the worlds fit words. In other words, speaker intends the situation. The commissive utterances consists of refusing, promising, volunteering, committing, guaranteeing, offering, effusing, etc.

Example: I will phone you at 7 o'clock.

This commissive utterance conveys the promising utterance.

Yule (2006) explains the three aspects of speech acts as follows:

\section{Locutionary Act}

Locutionary act is the basic act of utterance, or producing a meaningful linguistic expression (Yule, 1996). In other words, locutionay act can be defined as the act of making a meaningful utterance and using a referring expression. The speaker usually uses the identifiable expression to produce a meaningful expression to the hearer. In other words, locutionary act is an act to produce meaningful and understandable utterances. Every utterance expresssed is meaningful and understandable so the utterance will be identified further to decide if it is illocutionary act or perlocutionary act. The speaker who tounge tied can not speak properly so he or she failed in making locutionary act because the language is not understandable.

Example: Please come to my birthday party.

This is an example of locutionary act of inviting.

\section{Illocutionary act}

Illocutionary act is a complete speech act, an act of doing something which means the specific purpose of the speaker's intention in mind such as promising, stating, commanding, denial, prediction, request, confirming, etc.

Example: I swear that I will give it back to you.

This is an example of illocutionary act of promising.

\section{Perlocutionary Act}

Perlocutionary act is the reaction of the hearer, the consequences of saying something, intended or not. The effect after the speaker says something to the hearer; an act is performed as a reaction. The action of the hearer depends on what the speaker says. The effects may be actions, thoughts or feelings.

Example: There is something walking on your hair.

This utterance may cause a panic situation to the hearer. This perlocutionary act is to cause an emotional and panic situation.

Example Hey, you've just won a lottery!

This utterance of perlocutionary act may cause a happy and shocking situation to the hearer. 
According to Jucker and Taavitsainen (2008), directive speech acts contain a verb, an object and a requested task performed by the speaker and the hearer. Directive speech acts is an utterance of the speaker to make the hearer do something for the speaker. The directive speech acts are divided into 20 sub categories: 1) Advising, 2) admonishing, 3) asking, 4) begging, 5) challenging, 6) daring, 7) demanding, 8) dismissing, 9) excusing, 10) forbidding, 11) instructing, 12) inviting, 13) ordering, 14) permitting, 15) recommending, 16) requesting, 17) requiring, 18) suggesting, 19) urging and 20) warning. The example of directive speech act: "Don't go too far!" This is the example of directive speech acts of forbidding.

In this research, the analysis and discussion are focused on the directive speech acts only. The analysis will be elaborated in the following section.

\section{RESEARCH METHODS}

This research uses a qualitative method which means the qualitative data were collected and qualitatively interpreted. Theoretical framework for this study was obtained through a library research. The data for this thesis was taken from the movie script retrieved from the internet. The data will be analyzed by using speech acts theories. The other source of data was derived from the movie. The writers will analyze gestures or the body movements of the characters that can be seen from the movie to find out the hidden/implicit meaning that cannot be interpreted based on the script only.

According to Yule (1996), speech acts consist of five categories, they are: representative, declarative, expressive, directive and commisive. As stated before, this research will focus on directive speech acts only. Therefore, the existence of directive speech acts throughout the scenes of the movie was carefully noted and analyzed. All the data collected from this research were tabulated and analyzed based on their directive speech act sub-categories. As previously mentioned, directive speech act consists of 20 sub-categories, i.e. advising, admonishing, asking, begging, challenging, daring, demanding, dismissing, excusing, forbidding, instructing, inviting, ordering, permitting, recommending, requesting, requiring, suggesting, urging and warning (Jucker and Taavitsainen, 2008). Characters that perform similar category of directive speech acts were analyzed in the same table (due to limited space tables of analysis are not included in this article). Analysis on illocutionary and perlocutionary aspect of the directive speech acts was also given in each category. Responses of the hearers as the proof of the directive speech act performed were also analyzed. The utterances given in the table are the representations of each categories. The representations describe different style of each utterances so not all of the utterances will be explained in the table.

\section{RESULTS AND DISCUSSION}

It is necessary to know the characters in the movie as they are the ones who are involved in directive speech acts throughout the scenes of the movie. Those characters are:

\section{Princess Aurora/Briar Rose}

Aurora is the protagonist of "Sleeping Beauty". She was the only daughter of King Stefan and the Queen. She was cursed by Maleficent when she was a baby and saved by the three good fairies and the prince. After Maleficent cursed her, the three good fairies took her to the forest and changed her name into Briar Rose. Because of the gifts of the three good fairies when she was a baby, she grew into a beautiful young girl and had a beautiful voice. She had a golden long hair and red rose lips. She 
was also a kind, humble and a hardworking girl. Her curse broke by a kiss from Prince Philip. Prince Philip and she would be the successor of the throne.

\section{Prince Philip}

Philip was the hero of "Sleeping Beauty" and Aurora's true love. His father was King Hubert, King Stefan's friend. King Hubert was the king from another kingdom. He was a noble, brave, charming, full-spirited and humble prince. He had no fatal flaw as the hero of this movie. He fell in love at the first sight with Aurora. He could ride horse, sing, dance, and fight. He killed the evil witch, Maleficent and broke Aurora's curse. He is a typical of a fairy tale prince charming.

\section{King Stefan}

King Stefan was the current king of the kingdom. He was Aurora's father. He seemed as a wise king but sometimes he acted childish eventhough he was old enough. His dream was to unite his kingdom with Hubert's and had a granddaughter or grandson. His best friend is King Hubert from the neighborhood kingdom. They usually drank and had fun together. Their dream was to unite their kingdom so they betrothed Aurora and Philip when they were a baby and a kid. Because of Maleficent's curse to Aurora, King Stefan command to the entire kingdom to burn all spinning wheels in the castle to prevent the curse. He loved his daughter. He was very sad when the three good fairies took her to the forest and happy when Aurora was back.

\section{The Queen}

King Stefans's wife. She is almost has no dialogue in this movie. Her appearance also not as many as her husband, King Stefan. From her little appearance, we can conclude that she was a caring and patient mother. She only had one daughter, Aurora. She was very sad when knowing that Aurora must live separated from her after Maleficent put a curse to Aurora. She seemed to be a good wife to Stefan.

\section{King Hubert}

King Stefan's best friend from neighbourhood kingdom. They loved to have fun together. Drinking and laughing together like a child. He has the same personalities with King Stefan. It makes they match well each other. King Hubert's son was Philip, the only prince from his kingdom. Philip is a strong and playful prince. King Hubert often been tricked by Philip. King Hubert also loved his only son. He always wanted the best for Philip.

\section{Flora}

One of the three good fairies. She wore pink and red clothes and she was the wisest from the other good fairies. She acted like a leader. She was caring, had a good leadership and giving ideas to the other fairies. Her image is a caring grandmother to her granddaughter. Sometimes she had an argument with Merrywether, the other good fairy. She is the oldest in her group. She gave Aurora a gift of beauty.

\section{Fauna}

One of the three good fairies. She wore green clothes. She was the calmest fairy in her group. She was also the tallest. She did not argue much. She look more mature than the other good fairies. She even stay cool when facing Maleficent. She had a positive thinking to everything. She gave Aurora a gift of song, a beautiful voice. 


\section{Merrywether}

One of the three good fairies. She wore blue clothes. She was the shortest, the fattest and the youngest from the other good fairies. She often fought with Flora in order to decide what colour was appropriate to Aurora, red or blue. She often spoke sharply and sarcastically especially in facing Flora and Maleficent. She was also too aggressive when facing Maleficent. Before she gave a gift to Aurora, Maleficent came and curse Aurora. Because of that incident, Merrywether gave Aurora a gift that could break the curse that Maleficent put to Aurora, from death to a deep sleep until a true love's kiss could wake her up.

\section{Maleficent}

Maleficent was the main antagonist in this movie. She was the evil witch who put a curse to Aurora when she was a baby. She did that because she was not invited to the party of the newborn baby. Her presence is always symbolized by dark black or green aura. Her clothes are black, she used black magic and had raven pet as her loyal servant. She had many servants to serve her but they were too stupid. She met her doom in Prince Philip hand, died in a form of a dragon stabbed on the chest by Prince Philip.

Below are the analyses of the directive speech acts performed by the characters in the movie categorized into 20 categories of directive speech acts.

\section{Advising}

There are nine utterances of advising directive speech acts spoken by four characters. Among these advising directive speech acts, two utterances can be classified under illocutionary aspect as these speech acts reflect the intention of the speakers only. While seven directive speech of advising acts fall under the perlocutionary aspects because the speaker intention was responded by the real action of the hearer. The writers analyze the utterances by checking the body movements and gestures of each hearer who performed the advising directive speech acts. Here are the examples.

Table 1 Advising

\begin{tabular}{|c|c|c|c|c|c|c|c|}
\hline No. & $\begin{array}{l}\text { Character } \\
\text { (Speaker) }\end{array}$ & $\begin{array}{l}\text { Character } \\
\text { (Hearer) }\end{array}$ & Dialogue & Time & Scene & ILC & PLC \\
\hline 1 & Fauna & Merrywether & Just do your best, dear. & $10: 40-10: 41$ & 1 & & $\sqrt{ }$ \\
\hline 2 & Flora & King Stefan & $\begin{array}{l}\text { Don't despair, your majesties. } \\
\text { Merryweather still has her gift } \\
\text { to give. }\end{array}$ & $10: 20-10: 25$ & 1 & & $\sqrt{ }$ \\
\hline
\end{tabular}

ILC= Illocutionary act $\quad$ PLC=Perlocutionary Act

The dialogues above contain advising directive speech acts because the speakers give an advise to the hearer.

\section{Admonishing}

There are four utterances of admonishing directive speech acts spoken by four characters. Among these admonishing directive speech acts, one utterance can be classified under illocutionary aspect as these speech acts reflect the intention of the speakers only. While three utterances directive speech acts of admonishing fall under the perlocutionary aspects because the speaker intention was responded by the real action of the hearer. The writers analyze the utterances by checking the body movement and gesture of each hearer who performed the admonishing directive speech acts. Here are the examples. 
Table 2 Admonishing

\begin{tabular}{|c|c|c|c|c|c|c|c|}
\hline No. & $\begin{array}{l}\text { Character } \\
\text { (Speaker) }\end{array}$ & $\begin{array}{c}\text { Character } \\
\text { (Hearer) }\end{array}$ & Dialogue & Time & Scene & ILC & PLC \\
\hline 1 & Merrywether & Flora & $\begin{array}{l}\text { But you can't sow, and } \\
\text { she's never cooked! }\end{array}$ & $20: 51-20: 54$ & 4 & & $\sqrt{ }$ \\
\hline 2 & Maleficent & Merrywether & $\begin{array}{l}\text { I really felt quite } \\
\text { distressed of not } \\
\text { receiving an invitation. }\end{array}$ & 09:00-09:03 & 1 & & $\sqrt{ }$ \\
\hline
\end{tabular}

ILC= Illocutionary act $\quad$ PLC=Perlocutionary Act

The dialogues above contain admonishing directive speech acts because the hearers were being admonished by the speakers.

\section{Asking}

There are 12 utterances of asking directive speech acts spoken by four characters. Among these asking directive speech acts, two utterances can be classified under illocutionary aspect as these speech acts reflect the intention of the speakers only. While ten directive speech acts of asking fall under the perlocutionary aspects because the speaker intention was responded by the real action of the hearer. The writers analyze the utterances by checking the body movement and gesture of each hearer who performed the asking directive speech acts. Here are the examples.

Table 3 Asking

\begin{tabular}{|c|c|c|c|c|c|c|c|}
\hline No. & $\begin{array}{l}\text { Character } \\
\text { (Speaker) }\end{array}$ & $\begin{array}{c}\text { Character } \\
\text { (Hearer) }\end{array}$ & Dialogue & Time & Scene & ILC & PLC \\
\hline 1 & Flora & Fauna & Why not? & $14: 38-14: 41$ & 2 & & $\sqrt{ }$ \\
\hline 2 & Merrywether & Flora & But who'll wash, and cook? & $15: 18-15: 20$ & 2 & & $\sqrt{ }$ \\
\hline
\end{tabular}

The dialogues above contain asking directive speech acts because the speakers asked questions to the hearers.

\section{Begging}

There are four utterances of begging directive speech acts spoken by three characters. Among these begging directive speech acts, one utterance can be classified under illocutionary aspect as these speech acts reflects the intention of the speakers only. While three directive speech acts of begging fall under the perlocutionary aspects because the speaker intention was responded by the real action of the hearer. The writers analyze the utterances by checking the body movement and gesture of each hearer who performed the begging directive speech acts. Here are the examples.

Table 4 Begging

\begin{tabular}{|c|c|c|c|c|c|c|c|}
\hline No. & $\begin{array}{l}\text { Character } \\
\text { (Speaker) }\end{array}$ & $\begin{array}{l}\text { Character } \\
\text { (Hearer) }\end{array}$ & Dialogue & Time & Scene & ILC & PLC \\
\hline 1 & Flora & Merrywether & Let me have it, dear. & $15: 23-15: 26$ & 2 & & $\sqrt{ }$ \\
\hline 2 & Flora & Merrywether & $\begin{array}{l}\text { She's always wanted to, dear, } \\
\text { and this is her last chance. }\end{array}$ & $20: 40-20: 42$ & 4 & & $\sqrt{ }$ \\
\hline
\end{tabular}

ILC= Illocutionary act PLC=Perlocutionary Act 
The dialogues above contain begging directive speech acts because the speaker begged the hearer.

\section{Challenging}

There are nine utterances of begging directive speech acts spoken by five characters. Among these begging directive speech acts, one utterance can be classified under illocutionary aspect as these speech acts reflects the intention of the speakers only. While eight directive speech acts of challenging fall under the perlocutionary aspects because the speaker intention was responded by the real action of the hearer. The writers analyze the utterances by checking the body movement and gesture of each hearer who performed the challenging directive speech acts. Here are the examples.

Table 5 Challenging

\begin{tabular}{cccccccc}
\hline No. & $\begin{array}{c}\text { Character } \\
\text { (Speaker) }\end{array}$ & $\begin{array}{c}\text { Character } \\
\text { (Hearer) }\end{array}$ & \multicolumn{1}{c}{ Dialogue } & Time & Scene & ILC & PLC \\
\hline 1 & King Hubert & King Stefan & $\begin{array}{l}\text { Getting my Phillip aren't } \\
\text { you? }\end{array}$ & $43: 15-43: 16$ & 7 & $\sqrt{ }$ \\
\hline 2 & King Hubert & King Stefan & $\begin{array}{l}\text { Want to see our } \\
\text { grandchildren, don't we? }\end{array}$ & $43: 17-43: 18$ & 7 & $\sqrt{ }$ \\
\hline
\end{tabular}

ILC= Illocutionary act PLC=Perlocutionary Act

The dialogues above contain challenging directive speech acts because the speaker challenged the hearer.

\section{Daring}

There are five utterances of begging directive speech acts spoken by three characters. Among these begging directive speech acts, no utterances can be classified under illocutionary aspect because none of the hearers reflects the intention of the speakers. While five directive speech acts of daring fall under the perlocutionary aspects because the speaker intention was responded by the real action of the hearer. The writers analyze the utterances by checking the body movement and gesture of each hearer who performed the daring directive speech acts. Here are the examples.

Table 6 Daring

\begin{tabular}{|c|c|c|c|c|c|c|c|}
\hline No. & $\begin{array}{l}\text { Character } \\
\text { (Speaker) }\end{array}$ & $\begin{array}{c}\text { Character } \\
\text { (Hearer) }\end{array}$ & Dialogue & Time & Scene & ILC & PLC \\
\hline 1 & King Hubert & King Stefan & $\begin{array}{l}\text { Why, doesn't your daughter } \\
\text { like my son }\end{array}$ & $43: 47-43: 50$ & 7 & & $\sqrt{ }$ \\
\hline 2 & Merrywether & Maleficent & You weren't wanted! & 09:04-09:06 & 1 & & $\sqrt{ }$ \\
\hline
\end{tabular}
hearers.

The dialogues above contain daring directive speech acts because the speakers dared the

\section{Demanding}

There are six utterances of demanding directive speech acts spoken by four characters. Among these demanding directive speech acts, two utterances can be classified under illocutionary aspect as these speech acts reflect the intention of the speakers only. While four directive speech acts of 
demanding fall under the perlocutionary aspects because the speaker intention was responded by the real action of the hearer. The writers analyze the utterances by checking the body movement and gesture of each hearer who performed the demanding directive speech acts. Here are the examples.

Table 7 Demanding

\begin{tabular}{|c|c|c|c|c|c|c|c|}
\hline No. & $\begin{array}{l}\text { Character } \\
\text { (Speaker) }\end{array}$ & $\begin{array}{l}\text { Character } \\
\text { (Hearer) }\end{array}$ & Dialogue & Time & Scene & ILC & PLC \\
\hline 1 & Fauna & Flora & Don't forget a pretty bow. & 19:18-19:20 & 4 & & $\sqrt{ }$ \\
\hline 2 & Maleficent & $\begin{array}{l}\text { Maleficent's } \\
\text { servants }\end{array}$ & $\begin{array}{l}\text { But what about the town, the } \\
\text { forests, the mountains? }\end{array}$ & $17: 02-17: 13$ & 3 & & $\sqrt{ }$ \\
\hline
\end{tabular}

ILC= Illocutionary act PLC=Perlocutionary Act

The dialogues above contain demanding directive speech acts because the speakers demanded something to the hearers.

\section{Dismissing}

There is one utterance of dismissing directive speech acts spoken by one character. Among these dismissing directive speech acts, one utterance can be classified under illocutionary aspect as these speech acts reflects the intention of the speaker only. While one directive speech acts of dismissing falls under the perlocutionary aspects because the speaker intention was responded by the real action of the hearer. The writers analyze the utterances by checking the body movement and gesture of each hearer who performed the dismissing directive speech acts. Here is the example.

Table 8 Dismissing

\begin{tabular}{|c|c|c|c|c|c|c|c|}
\hline No. & $\begin{array}{l}\text { Character } \\
\text { (Speaker) }\end{array}$ & $\begin{array}{c}\text { Character } \\
\text { (Hearer) }\end{array}$ & Dialogue & Time & Scene & ILC & PLC \\
\hline 1 & Merrywether & Fauna & $\begin{array}{l}\text { Well, yes, yes, but will we } \\
\text { have to feed it? }\end{array}$ & $14: 45-14: 47$ & 2 & & $\sqrt{ }$ \\
\hline
\end{tabular}

ILC= Illocutionary act PLC=Perlocutionary Act

The dialogue above contains dismissing directive speech acts because the speaker dismissed something to the hearer.

\section{Excusing}

There are three utterances of excusing directive speech acts spoken by three characters. Among these excusing directive speech acts, no utterances can be classified under illocutionary aspect because none of the hearers reflect the intention of the speakers. While three directive speech acts of excusing fall under the perlocutionary aspects because the speaker intention was responded by the real action of the hearer. The writers analyze the utterances by checking the body movement and gesture of each hearer who performed the excusing directive speech acts. Here is the example.

Table 9 Excusing

\begin{tabular}{|c|c|c|c|c|c|c|c|}
\hline No. & $\begin{array}{l}\text { Character } \\
\text { (Speaker) }\end{array}$ & $\begin{array}{c}\text { Character } \\
\text { (Hearer) }\end{array}$ & Dialogue & Time & Scene & ILC & PLC \\
\hline 1 & Merrywether & Flora & $\begin{array}{l}\text { But, I never baked a } \\
\text { fancy cake. }\end{array}$ & $20: 32-20: 35$ & 4 & & $\sqrt{ }$ \\
\hline
\end{tabular}

ILC= Illocutionary act PLC=Perlocutionary Act 
The dialogue above contains excusing directive speech acts because the speaker excused something to the hearer.

\section{Forbidding}

There are eight utterances of forbidding directive speech acts spoken by five characters. Among these forbidding directive speech acts, one utterance can be classified under illocutionary aspect as these speech acts reflects the intention of the speakers only. While seven directive speech acts of forbidding fall under the perlocutionary aspects because the speaker intention was responded by the real action of the hearer. The writers analyze the utterances by checking the body movement and gesture of each hearer who performed the begging directive speech acts. Here is the example.

Table 10 Forbidding

\begin{tabular}{|c|c|c|c|c|c|c|c|}
\hline No. & $\begin{array}{l}\text { Character } \\
\text { (Speaker) }\end{array}$ & $\begin{array}{l}\text { Character } \\
\text { (Hearer) }\end{array}$ & Dialogue & Time & Scene & ILC & PLC \\
\hline 1 & Flora & Merrywether & $\begin{array}{l}\text { Oh, no, no, no, no, no magic! I'll } \\
\text { take those wands right now. Oh, } \\
\text { better get rid of those wings, too. }\end{array}$ & $14: 57-15: 10$ & 2 & & $\sqrt{ }$ \\
\hline
\end{tabular}

ILC= Illocutionary act PLC=Perlocutionary Act

The dialogue above contains forbidding directive speech acts because the speaker forbade the hearer to do something.

\section{Instructing}

There are eight utterances of instructing directive speech acts spoken by four characters. Among these instructing directive speech acts, no utterances can be classified under illocutionary aspect because none of the hearers reflect the intention of the speaker. While eight directive speech acts of instructing fall under the perlocutionary aspects because the speaker intention was responded by the real action of the hearer. The writers analyze the utterances by checking the body movement and gesture of each hearer who performed the instructing directive speech acts. Here is the example.

Table 11 Instructing

\begin{tabular}{|c|c|c|c|c|c|c|c|}
\hline No. & $\begin{array}{l}\text { Character } \\
\text { (Speaker) }\end{array}$ & $\begin{array}{c}\text { Character } \\
\text { (Hearer) }\end{array}$ & Dialogue & Time & Scene & ILC & PLC \\
\hline 1 & Fauna & Merrywether & All you do is follow the book. & $19: 57-19: 58$ & 4 & & $\sqrt{ }$ \\
\hline
\end{tabular}

ILC= Illocutionary act PLC=Perlocutionary Act

The dialogue above contains instructing directive speech acts because the speaker instructed the hearer to do something.

\section{Inviting}

There is one utterance of inviting directive speech acts spoken by one character. Among these inviting directive speech acts, no utterances can be classified under illocutionary aspect because none of the hearer reflects the intention of the speaker. While one directive speech acts of inviting fall under the perlocutionary aspects because the speaker intention was responded by the real action of the hearer. The writers analyze the utterances by checking the body movement and gesture of each hearer who performed the inviting directive speech acts. Here is the example. 
Table 12 Inviting

\begin{tabular}{|c|c|c|c|c|c|c|c|}
\hline No. & $\begin{array}{l}\text { Character } \\
\text { (Speaker) }\end{array}$ & $\begin{array}{c}\text { Character } \\
\text { (Hearer) }\end{array}$ & Dialogue & Time & Scene & ILC & PLC \\
\hline 1 & Flora & Aurora & All right, in here, dear. & $48: 59-49: 03$ & 8 & & $\sqrt{ }$ \\
\hline
\end{tabular}

ILC= Illocutionary act PLC=Perlocutionary Act

The dialogue above contains inviting directive speech acts because the speaker invited the hearer to do something.

\section{Ordering}

There are 30 utterances of ordering directive speech acts spoken by seven characters. Among these ordering directive speech acts, three utterances can be classified under illocutionary aspect as these speech acts reflect the intention of the speakers only. While 27 directive speech acts of ordering fall under the perlocutionary aspects because the speaker intention was responded by the real action of the hearer. The writers analyze the utterances by checking the body movement and gesture of each hearer who performed the ordering directive speech acts. Here is the example.

Table 13 Ordering

\begin{tabular}{|c|c|c|c|c|c|c|c|}
\hline No. & $\begin{array}{l}\text { Character } \\
\text { (Speaker) }\end{array}$ & $\begin{array}{c}\text { Character } \\
\text { (Hearer) }\end{array}$ & Dialogue & Time & Scene & ILC & PLC \\
\hline 1 & King Stefan & Soldiers & Seize that creature! & 10:04-10:06 & 1 & & $\sqrt{ }$ \\
\hline
\end{tabular}

The dialogue above contains ordering directive speech acts because the speaker ordered the hearer to do something.

\section{Permitting}

There are three utterances of permitting directive speech acts spoken by three characters. Among these permitting directive speech acts, two utterances can be classified under illocutionary aspect as these speech acts reflect the intention of the speakers only. While one directive speech acts of permitting falls under the perlocutionary aspects because the speaker intention was responded by the real action of the hearer. The writers analyze the utterances by checking the body movement and gesture of each hearer who performed the permitting directive speech acts. Here is the example.

Table 14 Permitting

\begin{tabular}{|c|c|c|c|c|c|c|c|}
\hline No. & $\begin{array}{l}\text { Character } \\
\text { (Speaker) }\end{array}$ & $\begin{array}{c}\text { Character } \\
\text { (Hearer) }\end{array}$ & Dialogue & Time & Scene & ILC & PLC \\
\hline 1 & King Hubert & King Stefan & $\begin{array}{l}\text { Want to see our } \\
\text { grandchildren, don't we? }\end{array}$ & $43: 17-43: 18$ & 7 & & $\sqrt{ }$ \\
\hline
\end{tabular}

The dialogue above contains permitting directive speech acts because the speaker permitted the hearer to do something. 


\section{Recommending}

There are four utterances of recommending directive speech acts spoken by two characters. Among these recommending directive speech acts, one utterance can be classified under illocutionary aspect as these speech acts reflects the intention of the speakers only. While three directive speech acts of recommending fall under the perlocutionary aspects because the speaker intention was responded by the real action of the hearer. The writers analyze the utterances by checking the body movement and gesture of each hearer who performed the recommending directive speech acts. Here is the example.

Table 15 Recommending

\begin{tabular}{|c|c|c|c|c|c|c|c|}
\hline No. & $\begin{array}{l}\text { Character } \\
\text { (Speaker) }\end{array}$ & $\begin{array}{l}\text { Character } \\
\text { (Hearer) }\end{array}$ & Dialogue & Time & Scene & ILC & PLC \\
\hline 1 & Flora & Merrywether & $\begin{array}{l}\text { Now I thought a few } \\
\text { changes here ... }\end{array}$ & $19: 14-19: 16$ & 4 & & $\sqrt{ }$ \\
\hline
\end{tabular}

The dialogue above contains recommending directive speech acts because the speaker recommended the hearer to do something.

\section{Requesting}

There are five utterances of requesting directive speech acts spoken by four characters. Among these requesting directive speech acts, two utterances can be classified under illocutionary aspect as these speech acts reflect the intention of the speakers only. While three directive speech acts of requesting fall under the perlocutionary aspects because the speaker intention was responded by the real action of the hearer. The writers analyze the utterances by checking the body movement and gesture of each hearer who performed the requesting directive speech acts. Here is the example.

Table 16 Requesting

\begin{tabular}{cccccccc}
\hline No. & $\begin{array}{c}\text { Character } \\
\text { (Speaker) }\end{array}$ & $\begin{array}{c}\text { Character } \\
\text { (Hearer) }\end{array}$ & Dialogue & Time & Scene & ILC & PLC \\
\hline 1 & Merrywether & Flora & $\begin{array}{l}\text { Want you to pick } \\
\text { some berries. }\end{array}$ & 19:40-19:44 & 4 & & V \\
\hline ILC= & Illocutionary act & PLC=Perlocutionary Act & & & &
\end{tabular}

The dialogue above contains requesting directive speech acts because the speaker requested the hearer to do something.

\section{Requiring}

There are three utterances of requiring directive speech acts spoken by two characters. Among these requiring directive speech acts, no utterances can be classified under illocutionary aspect because none of the hearers reflect the intention of the speaker. While three directive speech acts of requiring fall under the perlocutionary aspects because the speaker intention was responded by the real action of the hearer. The writers analyze the utterances by checking the body movement and gesture of each hearer who performed the requiring directive speech acts. Here is the example. 
Table 17 Requiring

\begin{tabular}{cccccccc}
\hline No. & $\begin{array}{c}\text { Character } \\
\text { (Speaker) }\end{array}$ & $\begin{array}{c}\text { Character } \\
\text { (Hearer) }\end{array}$ & \multicolumn{1}{c}{ Dialogue } & Time & Scene & ILC & PLC \\
\hline 1 & Flora & Fauna & $\begin{array}{l}\text { Of course, we'll need } \\
\text { a few pleats }\end{array}$ & $19: 22-19: 26$ & 4 & & $\sqrt{ }$ \\
\hline
\end{tabular}

ILC = Illocutionary act PLC=Perlocutionary Act

The dialogue above contains requiring directive speech acts because the speaker required the hearer to do something.

\section{Suggesting}

There are seven utterances of suggesting directive speech acts spoken by four characters. Among these suggesting directive speech acts, three utterances can be classified under illocutionary aspect as these speech acts reflect the intention of the speakers only. While four directive speech acts of suggesting fall under the perlocutionary aspects because the speaker intention was responded by the real action of the hearer. The writers analyze the utterances by checking the body movement and gesture of each hearer who performed the suggesting directive speech acts. Here is the example.

Table 18 Suggesting

\begin{tabular}{|c|c|c|c|c|c|c|c|}
\hline No. & $\begin{array}{l}\text { Character } \\
\text { (Speaker) }\end{array}$ & $\begin{array}{c}\text { Character } \\
\text { (Hearer) }\end{array}$ & Dialogue & Time & Scene & ILC & PLC \\
\hline 1 & Fauna & $\begin{array}{l}\text { Flora, } \\
\text { Merrywether }\end{array}$ & $\begin{array}{l}\text { Well, perhaps if we } \\
\text { reason with her. }\end{array}$ & $12: 06-12: 08$ & 2 & & $\sqrt{ }$ \\
\hline
\end{tabular}

ILC= Illocutionary act $\quad$ PLC=Perlocutionary Act

The dialogue above contains suggesting directive speech acts because the speaker suggested something to the hearer.

\section{Urging}

There are five urging directive speech acts spoken by five characters. Among these urging directive speech acts, no utterances can be classified under illocutionary aspect because none of the hearers reflect the intention of the speaker. While five directive speech acts of urging fall under the perlocutionary aspects because the speaker intention was responded by the real action of the hearer. The writers analyze the utterances by checking the body movement and gesture of each hearer who performed the begging directive speech acts. Here is the example.

Table 19 Urging

\begin{tabular}{ccccccc}
\hline No. & $\begin{array}{l}\text { Character } \\
\text { (Speaker) }\end{array}$ & $\begin{array}{c}\text { Character } \\
\text { (Hearer) }\end{array}$ & Time & Scene & ILC & PLC \\
\hline 1 & Flora & $\begin{array}{l}\text { Princess Aurora. Tonight, we're } \\
\text { taking you back to your father, } \\
\text { King Stefan. }\end{array}$ & 39:52-39:55 & 6 & $\sqrt{ }$ \\
\hline ILC= Illocutionary act $\quad$ PLC=Perlocutionary Act &
\end{tabular}

The dialogue above contains urging directive speech acts because the speaker urged the hearer to do something. 


\section{Warning}

There are 12 warning directive speech acts spoken by three characters. Among these warning directive speech acts, no utterances can be classified under illocutionary because none of the hearers reflect the intention of the speakers. While 12 directive speech acts of warning fall under the perlocutionary aspects because the speaker intention was responded by the real action of the hearer. The writers analyze the utterances by checking the body movement and gesture of each hearer who performed the warning directive speech acts. Here is the example.

Table 20 Warning

\begin{tabular}{|c|c|c|c|c|c|c|c|}
\hline No. & $\begin{array}{l}\text { Character } \\
\text { (Speaker) }\end{array}$ & $\begin{array}{c}\text { Character } \\
\text { (Hearer) }\end{array}$ & Dialogue & Time & Scene & ILC & PLC \\
\hline 1 & Flora & $\begin{array}{l}\text { Fauna, } \\
\text { Merrywether }\end{array}$ & $\begin{array}{l}\text { I'm going to ... shh, shh, } \\
\text { shh! Even walls have ears. }\end{array}$ & $12: 40-12: 44$ & 2 & & $\sqrt{ }$ \\
\hline
\end{tabular}

ILC= Illocutionary act $\quad$ PLC=Perlocutionary Act

The dialogue above contains warning directive speech acts because the speaker gave warning to the hearers.

\section{The Summary of Directive Speech Act Occurrences}

Based on the analyses given, below is the summary of directive speech act occurrences in the movie. It is summarized in the form of a table.

Table 21 Summary of Directive Speech Act Occurences

\begin{tabular}{clccc}
\multirow{2}{*}{ No. } & Directive Speech Act Sub-Categories & \multicolumn{2}{c}{ Frequency } & \multirow{2}{*}{ Percentage } \\
\cline { 3 - 4 } & & ILC & PLC & \\
\hline 1 & Advising & 2 & 7 & $6.5 \%$ \\
2 & Admonishing & 1 & 3 & $2.9 \%$ \\
3 & Asking & 2 & 10 & $8.6 \%$ \\
4 & Begging & 1 & 3 & $2.9 \%$ \\
5 & Challenging & 1 & 8 & $6.5 \%$ \\
6 & Daring & 0 & 5 & $3.6 \%$ \\
7 & Demanding & 1 & 5 & $4.3 \%$ \\
8 & Dismissing & 1 & 1 & $1.4 \%$ \\
9 & Excusing & 0 & 3 & $2.1 \%$ \\
10 & Forbidding & 1 & 7 & $5.8 \%$ \\
11 & Instructing & 0 & 7 & $5.0 \%$ \\
12 & Inviting & 0 & 1 & $0.7 \%$ \\
13 & Ordering & 3 & 27 & $21.6 \%$ \\
14 & Permitting & 2 & 1 & $2.1 \%$ \\
15 & Recommending & 1 & 3 & $2.9 \%$ \\
16 & Requesting & 2 & 3 & $3.6 \%$ \\
17 & Requiring & 0 & 3 & $2.1 \%$ \\
18 & Suggesting & 3 & 4 & $5.0 \%$ \\
19 & Urging & 0 & 5 & $3.6 \%$ \\
20 & Warning & 0 & 12 & $8.6 \%$ \\
\hline & & $\mathbf{2 1}$ & $\mathbf{1 1 8}$ & $\mathbf{1 0 0 \%}$ \\
\hline
\end{tabular}

Total of directive speech acts occurrences is $=\mathrm{ILC}+\mathrm{PLC}=21+118=139$

Percentage is calculated using this formula $=\frac{\text { ILC }+ \text { PLC }}{\text { Total (139) }} X^{100 \%=\ldots}$ 
The table of summary proves that directive speech acts are used 118 times throughout the movie. The most frequently used illocutionary aspect is in ordering and suggesting sub-categories with total three occurrences in each sub-category. The writers did not find any illocutionary aspect under daring, excusing, instructing, inviting, requiring, urging and warning sub-categories. The most frequently used perlocutionary aspect is in ordering sub-category with total 27 utterances. The least used perlocutionary aspect is in dismissing, inviting and permitting directive speech acts with total one utterance in each sub-category. The most frequently used sub-category of directive speech acts is ordering directive speech acts with $21.6 \%$ and the least used sub-category of directive speech acts is inviting directive speech acts with $0.7 \%$.

\section{The Importance of Directive Speech Acts}

Directive speech acts play very important roles in keeping the smooth flow of storylines of the movie. Without directive speech acts, the storylines will be monotonous and not attractive. The following examples prove about it.

Table 22 Examples of the importance of directive speech acts

\begin{tabular}{ccllcc}
\hline No. & $\begin{array}{c}\text { Character } \\
\text { (Speaker) }\end{array}$ & $\begin{array}{c}\text { Character } \\
\text { (Hearer) }\end{array}$ & \multicolumn{1}{c}{ Dialogue } & Time & Scene \\
\hline 1 & King Stefan & Soldiers & Seize that creature! & 10:04-10:06 & 1 \\
\hline 2 & Flora & Merrywether & $\begin{array}{l}\text { If humans can do } \\
\text { it, so can we. }\end{array}$ & 14:52-14:53 & 2 \\
\hline
\end{tabular}

The examples show that the importance of directive speech acts in the movie. At the first example, if King Stefan did not order the soldiers to seize Maleficent, the soldiers would never want to seize Maleficent and Maleficent would not run away. At the second example, if Flora did not motivate Merrywether to disguise herself as a human and did human chores, she would never be a human and could not help Aurora. The storyline will be different and monotonous because a movie must have a plot leading to the ending which is supported by the existence of directive speech acts in this movie.

\section{CONCLUSIONS}

The analysis and discussion lead to the following conclusions. "Sleeping Beauty" movie contains many interesting and memorable dialogues that can be categorized as the directive speech acts. The conversations in the movies attract us from the way of speaking, acting and body movement. It also happens in "Sleeping Beauty", the drama and live action help viewers to focus on what the characters are doing. Based on the data analysis, it can be concluded that directive speech acts are essential actions in social interactions, they are also applied in the movie. Directive speech acts cannot be separated from daily social interactions; therefore, Walt Disney uses them in their movie to show that the movie represents the social interaction of human life. Based on the data analysis, the directive speech acts are frequently performed in the movie. It can be seen from the analysis in the previous section that elaborates the use of the directive speech acts. The results of the analysis show that 139 directive speech acts are performed in the movie. The summary shows that the directive speech acts of ordering is the most frequently used in the movie $(21.6 \%)$. The percentage shows the most frequently used directive speech acts by calculating the percentage of each categories of directive speech acts. While the least used directive speech acts are the directive speech act of inviting $(0.7 \%)$.

By watching this movie, the viewer will learn about words, action and utterances. The viewer can learn about pragmatics, especially speech acts by observing the dialogues and their context in 
every scene of the movie. The viewer can see the importance of directive speech acts in keeping the smooth flow of the story lines of the movie. The viewer can also learn grammar, pronounciation, and vocabulary from what they see and hear. They can imitate the action that the characters performing in the movie.

Based on the conclusions above, the writers would like to offer some suggestions. First, many people can learn speaking skill in addition to directive speech acts from "Sleeping Beauty". The writers hope that many people will benefit from watching this movie not just for entertainment but also for study. For example, many schools and universities nowadays use movies not only to teach directive speech acts but also to help the students to improve their speaking ability. Second, the study in this thesis is only focused on the directive speech acts. More comprehensive research on the psychological aspects of illocutionary and perlocutionary speech acts in this movie will be very interesting to do. Through this study we will have better understanding why and how people react or response to directive speech acts based on the psycho-analysis.

\section{BIBLIOGRAPHY}

Ahmed, S. (2005). The Non-Performativity of Anti-Racism. Borderlands e-journal , 5. sl.:sn.

Austin, J. L. (1962). How to do Things with Words (2th ed.). London: Routledge.

Horn, L. R., \& Ward, G. (2004). The Handbook of Pragmatics. Oxford: Blackwell.

Hurford, J. R., Heasley, B., Smith, M. B. (2007). Semantics: A Coursebook. New York: Cambridge University Press.

Jucker, A. H., \& Taavitsainen, I. (2008). Speech Acts in the History of English. Amsterdam: John Benjamins.

Nastri, J., Peña, J., \& Hancock, J. T. (2006). The Construction of Away Messages: A Speech Act Analysis . Journal of Computer-Mediated Communication.

Sinha, M. P. (2005). Modern Linguistics. New Delhi: Atlantic Publishers \& Distributors.

Stanford Encyclopedia of Philosophy. (2006, 28 November). Pragmatics. Retrieved September, $9^{\text {th }}$ 2013 from http://plato.stanford.edu/entries/pragmatics/

Yule, G. (1996). Pragmatics. New York: Oxford University Press. 